\title{
Laboratory studies on benzene sorption processes in clay formations
}

\author{
Krzysztof Wołowiec ${ }^{1}$, Grzegorz Malina² \\ ${ }^{1}$ Przedsiębiorstwo Geologiczne Sp. z o.o.; ul. Hauke Bosaka 3A, 25-214 Kielce, Poland; e-mail: kwolowiec@pgkielce.pl \\ ${ }^{2}$ AGH University of Science and Technology, Faculty of Geology, Geophysics and Environmental Protection, \\ al. Mickiewicza 30, Krakow, Poland; e-mail: gmalina@agh.edu.pl
}

\begin{abstract}
(C) 2015 Authors. This is an open access publication, which can be used, distributed and reproduced in any medium according
\end{abstract} to the Creative Commons CC-BY 4.0 License requiring that the original work has been properly cited.

Received: 5 December 2014; accepted: 17 April 2015

\begin{abstract}
The presented studies focused on benzene sorption mechanisms in the semi-permeable geological formations (aquitards). Clay formations were taken under consideration as not well investigated so far. Natural clay samples artificially contaminated with benzene were used in batch and column experiments to determine benzene partitioning and retardation in the studied clay material, and to reflect natural groundwater flow conditions. Column tests were carried out under controlled water flow conditions and using undisturbed clay samples. Benzene concentrations in tested samples (water and soil) were determined by gas chromatography (GC-FID). The linear sorption isotherm was used to fit the experimental data, as well as calculate the distribution coefficient $\left(K_{d}=0,042\right)$ and the retardation factor $(R=1.21)$ of benzene in the studied clay material. These parameters are important for mathematical modelling of the fate and transport of benzene through the semi-permeable formations (clays) to assess the associated risk and to prevent groundwater resources from contamination.
\end{abstract}

Keywords: sorption processes, retardation factor, clays, benzene

\section{INTRODUCTION}

Petroleum products are organic compounds derived from oil extraction and production industries and transport. They comprise a large group of chemicals such as: aliphatic and aromatic hydrocarbons, chlorinated hydrocarbons and phenols (Witczak \& Adamczyk 1995, Pinedo et al. 2013). When released to the environment they can contaminate soil-water systems (i.e. soil, soil vapours and groundwater). Physical-chemical properties of petroleum compounds (solubility, density, viscosity, volatility) are very important in terms of both: their migration in soil and groundwater and subsequent remediation of polluted sites. Petroleum compounds can be present in soil-water systems as a free-phase (non-aqueous phase liquids - NAPLs), volatile organic compounds (VOCs), sorbed to soil matrix or dissolved in groundwater. Migration of petroleum hydrocarbons in soil-water systems is determined by such processes as: advection, diffusion, dispersion, sorption and degradation (Rembeza 1998, Bolt \& Dobkowska 2000, Małecki 2006, Macioszczyk \& Dobrzyński 2007, Malina 2011).

Among petroleum compounds the mono-aromatic hydrocarbons (benzene, toluene, xylenes known as BTEX) are subjects of particular interest due to the hazard they may pose to the environment including living organisms. Because of their high water solubility they may dissolve in water saturated pores (Jeong \& Charbeneau 2014). If there is no water connections between the pores diffusion can still occur through the organic net in the rock matrix (Minnich 1993). As a result, saturated hydrocarbons may penetrate faster than the aromatic ones with the same numbers of carbon atoms. Diffusion of hydrocarbons in bedrock formations may take place in pores saturated with 
water, as well as filled with bitumic substances and/or organic matter. It means that hydrocarbons can migrate through the formations of very low permeability (Osmęda-Ernst \& Witczak 1991).

Benzene is widely used in many industries also as a starting material in organic synthesis. It is toxic and cancerogenic to living organisms, and its presence in the environment is often related to petroleum contamination. Because of higher solubility in water comparing to alkanes benzene is mobile and can easily migrate in groundwater.

Clay formations due to low permeability can be considered as protective layers against horizontal penetration of benzene (and other hydrocarbons) to deeper aquifers. A number of studies confirm the sorption properties of clays for hydrocarbon compounds (e.g. Izdebska-Mucha 2005, 2008). They are also well known as efficient sorbents of metals (Kubilay et al. 2007, Ayala et al. 2008). All factors mentioned above make hydrocarbon migration in low permeable formations very complex to study.

This research is aimed at determining the mechanisms of benzene (as a representative of the BTEX compounds) sorption in particular low-permeable clay formations. It is very important in terms of protection and determination of the risk of water resources contamination when remediation decisions have to be made. Another goal is to check the applicability of column experiments to evaluate retardation coefficient in low permeable materials. Compared to well-known batch tests the application of column experiments allows to reproduce dynamic conditions similar to the reality. However, currently in literature it is advised to use column tests for permeable materials and batch tests for low permeable materials. We tried to answer, if the traditional column experimental setup can be used for low permeable materials, what are the problems in performing such experiments, and how the conventional column experimental setup should be modified to avoid them.

\section{MATERIALS AND METHODS}

Laboratory tests concerned clay materials collected as undisturbed samples by drilling rig from an industrial site in Poland contaminated with petroleum. Sampling was accomplished by using a thin-walled, steel Shelby probe connected to a drilling rig. The probe length was of 500 millimeters with the inner diameter of 100 millimeters. The sample extraction was carried out with piston by a lifting method. The sampling procedure was performed in accordance with the Polish Standard PN-74-B-04452. The following analyses of the clays were performed: humidity, bulk density and bulk density of the soil skeleton by weight method, porosity calculated from bulk density as a ratio of pores volume to a total sample volume, total surface area by the methylene blue sorption method and filtration coefficient by the oedometer test. Physical properties of the clay samples were determined according to the Polish Standard (PN-B-04481:1988). All laboratory tests and experiments were performed in the laboratory of Przedsiębiorstwo Geologiczne Sp. z o.o. in Kielce. The deionized water was used for all performed tests. The concentrations of benzene in water solutions were determined using gas chromatography GC (Shimadzu GC-17A) with the flame ionized detector (FID). Chloride ions concentrations were determined by the titration method using silver nitrate as a titration solution (the Mohr method).

\section{BATCH EXPERIMENTS}

The goal of the batch tests was to determine the partitioning coefficient (distribution constant) and the retardation coefficient due to benzene sorption on clays from the sorption isotherms.

\section{Determination of equilibrium time of benzene sorption on studied clays}

$95 \mathrm{~g}$ of clays were placed into $50 \mathrm{~cm}^{3}$ glass bottles filled with a water solution of benzene with the concentration of $30.5 \mathrm{mg} / \mathrm{dm}^{3}$ commonly found in similar industrial sites in our previous studies. In order to eliminate microbial degradation of benzene sodium azide $\left(\mathrm{NaN}_{3}\right)$ was added. All bottles were completely filled with the solution and closed to avoid headspace. The experiment was carried out in room temperature $\left( \pm 20^{\circ} \mathrm{C}\right)$. Bottles were shaken during 24 hours at a rate of $450 \mathrm{rev} . / \mathrm{min}$ and tested for benzene concentrations in solution by GC-FID after 1, 2, 4, 6, 11 and 16 days. All tests were repeated six times to obtain a reliable data set for the statistical analysis. 


\section{Determination of sorption isotherm and partitioning coefficient (distribution constant)}

$100 \mathrm{~g}$ of clay was placed into $50 \mathrm{~cm}^{3}$ glass bottles to which water solutions of benzene with 4 different concentrations (10.00, 18.72, 26.79 and $30.53 \mathrm{mg} / \mathrm{dm}^{3}$ ) were added. In order to eliminate biodegradation of benzene during the experiment $\mathrm{NaN}_{3}$ was added. All bottles were completely filled with the solutions and closed to avoid headspace. The experiment was carried out in room temperature $\left( \pm 20^{\circ} \mathrm{C}\right)$. Bottles were shaken during 24 hours with a rate of $450 \mathrm{rev} . / \mathrm{min}$., then left for 48 hours in dark and tested for benzene concentrations in the solutions by GC-FID. The equilibrium concentration of benzene in the solution after sorption on clays was calculated from the mass balance:

$$
S=\left(C_{0}-C_{\mathrm{eq}}\right) \cdot V / m
$$

where:

$S$ - benzene content in clays under equilibrium conditions $[\mathrm{mg} / \mathrm{g}]$,

$C_{0}$ - initial benzene concentration in solution $\left[\mathrm{mg} / \mathrm{dm}^{3}\right]$,

$C_{\text {eq }}$ - final benzene concentration in solution $\left[\mathrm{mg} / \mathrm{dm}^{3}\right]$,

$V$ - volume of solution used $\left[\mathrm{dm}^{3}\right]$,

$m$ - mass of clay used [g].

There are different sorption models available to explain sorption mechanism (Tab. 1).

Table 1

Different sorption models (Delle Site 2001)

\begin{tabular}{|l|c|c|}
\hline \multicolumn{1}{|c|}{$\begin{array}{c}\text { Sorption } \\
\text { model }\end{array}$} & $\begin{array}{c}\text { Model } \\
\text { formula }\end{array}$ & $\begin{array}{c}\text { Retardation } \\
\text { coefficient }\end{array}$ \\
\hline Linear model & $S=K_{d} C_{\mathrm{eq}}$ & $R=1+\frac{\rho_{d}}{n_{0}} K_{d}$ \\
\hline $\begin{array}{l}\text { Freundlich's } \\
\text { model }\end{array}$ & $S=K_{F} C_{\mathrm{eq}}{ }^{\eta}$ & $R=1+\frac{\rho_{d}}{n_{0}} K_{F} C_{\mathrm{eq}}{ }^{\eta-1}$ \\
\hline $\begin{array}{l}\text { Langmuir's } \\
\text { model }\end{array}$ & $S=\frac{b K_{L} C_{\mathrm{eq}}}{1+K_{L} C_{\mathrm{eq}}}$ & $R=1+\frac{\rho_{d}}{n_{0}} \frac{b K_{L}}{\left(1+K_{L} C_{\mathrm{eq}}\right)^{2}}$ \\
\hline
\end{tabular}

Notation: $S$ - equilibrium sorbate concentration in sorbent $[\mathrm{mg} / \mathrm{g}], C_{e q}-$ equilibrium sorptive concentration in solution $\left[\mathrm{mg} / \mathrm{dm}^{3}\right], K_{d, F, L}-$ the distribution constants $\left[\mathrm{dm}^{3} / g\right], b-$ maximum sorption capacity of the sorbent $[\mathrm{mg} / \mathrm{g}], \eta$ - function exponent $[-], r_{d}-$ bulk density of the soil skeleton of the sorbent $\left[\mathrm{mg} / \mathrm{dm}^{3}\right], n_{0}-$ sorbent porosity [ - ]
Based on the experimental results the benzene sorption isotherm was plotted using the linear model selected for this study and described by equation (2) (Greg \& Sing 1982, Breus \& Mishchenko 2006, Qu et al. 2009):

$$
S=K_{d} \cdot C_{\mathrm{eq}}
$$

where:

$S$ - benzene concentration in clays under equilibrium conditions $[\mathrm{mg} / \mathrm{g}]$,

$K_{d}$ - the distribution constant $\left[\mathrm{dm}^{3} / \mathrm{g}\right]$,

$C_{\mathrm{eq}}$ - final benzene concentration in solution $\left[\mathrm{mg} / \mathrm{dm}^{3}\right]$.

The distribution constant $\left(K_{d}\right)$ derived from the sorption isotherm was used to determine the retardation coefficient $(R)$ for benzene migration in tested clays using equation (3) (Małecki 2006):

$$
R=1+\frac{\rho_{d}}{n_{0}} \cdot K_{d}
$$

where:

$$
\begin{aligned}
& R-\text { retardation coefficient }[-], \\
& \rho_{d}-\text { soil bulk density }\left[\mathrm{mg} / \mathrm{dm}^{3}\right], \\
& n_{0}-\text { porosity }[-] .
\end{aligned}
$$

\section{THE COLUMN EXPERIMENT}

The goal of the column experiment was to determine under dynamic conditions the retardation coefficient $(R)$ due to sorption of benzene on the studied clays. An undisturbed clay sample of $100 \mathrm{~g}$ was placed into a column made of stainless steel in order to provide high resistance on aggressive chemicals. All connections like: pipes, valves and seals were made of inert materials and verified by a blank test (benzene solution passed through an empty column and its concentrations were compared in the inlet and outlet water). A peristaltic pump connected to the column was used to force the benzene solution flow through the tested clays. The solution (with a benzene concentration of $30 \mathrm{mg} / \mathrm{dm}^{3}$ ) was prepared by dissolving benzene in a water-chloride solution. Chloride ions played a role of marker with no migration delay. The solution was pumped from the bottom of the column to avoid irregular flow conditions. The flow rate (q) through the clays was set as $0.75 \mathrm{~cm}^{3} / \mathrm{min}$ $\left(4.5 \cdot 10^{-5} \mathrm{~m}^{3} / \mathrm{h}\right)$. Considering the flow rate, effective porosity of clays and geometry of the column used 
in this test approximately 5 hours was required for pore volume $(P V)$ exchange according to the equation (4) (Marciniak et al. 2006):

$$
n_{e}=\frac{q t_{0}}{\Pi L r^{2}}
$$

where:

$$
\begin{aligned}
& n_{e} \text { - effective porosity }[-], \\
& q \text { - flow rate }\left[\mathrm{m}^{3} / \mathrm{h}\right], \\
& t_{0} \text { - time for pore volume exchange }[\mathrm{h}], \\
& L \text { - column length }[\mathrm{m}], \\
& r \text { - column radius }[\mathrm{m}] .
\end{aligned}
$$

The experiment was carried out in triplicate in room temperature $\left( \pm 20^{\circ} \mathrm{C}\right)$. During the experiment the eluate from the column was collected continuously to determine benzene and chloride ion concentrations as a function of time. The experimental set-up (Fig. 1) was slightly modified compared to that dedicated for permeable materials (Małecki 2006) by applying a peristaltic pump instead of column units to enforce the water flow through the low permeable clays.

The retardation coefficient was calculated according to equation (5) (Małecki 2006):

$$
R=\frac{t_{0}^{x}}{t_{0}}
$$

where:

$t_{0}^{x}$ - average time of benzene migration through the column [h],

$t_{0}$ - chloride ion migration time through the column [h].

\section{RESULTS}

The physical properties of clays used in the experiments are presented in Table 2. The mineral composition of tested clay has not been investigated and it should be considered in further works.

Table 2

Physical properties of clays used in the experiments

\begin{tabular}{|l|c|}
\hline \multicolumn{1}{|c|}{ Tested property } & $\begin{array}{c}\text { Test } \\
\text { results }\end{array}$ \\
\hline Sampling depth $[\mathrm{m} \mathrm{bgl]}$ & $14.6-16.5$ \\
\hline Humidity [\%] & 14.93 \\
\hline Bulk density $\rho\left[\mathrm{g} / \mathrm{cm}^{3}\right]$ & 2.10 \\
\hline Bulk density of the soil skeleton $d\left[\mathrm{~g} / \mathrm{cm}^{3}\right]$ & 1.83 \\
\hline Density of the soil skeleton $\rho_{s}\left[\mathrm{~g} / \mathrm{cm}^{3}\right]$ & 2.69 \\
\hline Porosity $n_{0}[\%]$ & 31.97 \\
\hline Total surface area $S_{t}\left[\mathrm{~m}^{2} / \mathrm{g}\right]$ & 56.96 \\
\hline Filtration coefficient $k_{10}[\mathrm{~m} / \mathrm{s}]$ & $9.8 \cdot 10^{-9}$ \\
\hline
\end{tabular}

The changes in benzene concentrations in solution of two subsequent measurements less than $\pm 1 \%$ were set as a criterion for reaching the system equilibrium state. The equilibrium of benzene sorption on the studied clays was reached after 4 days (Fig. 2) and this time was used in further tests to determine the sorption isotherm.

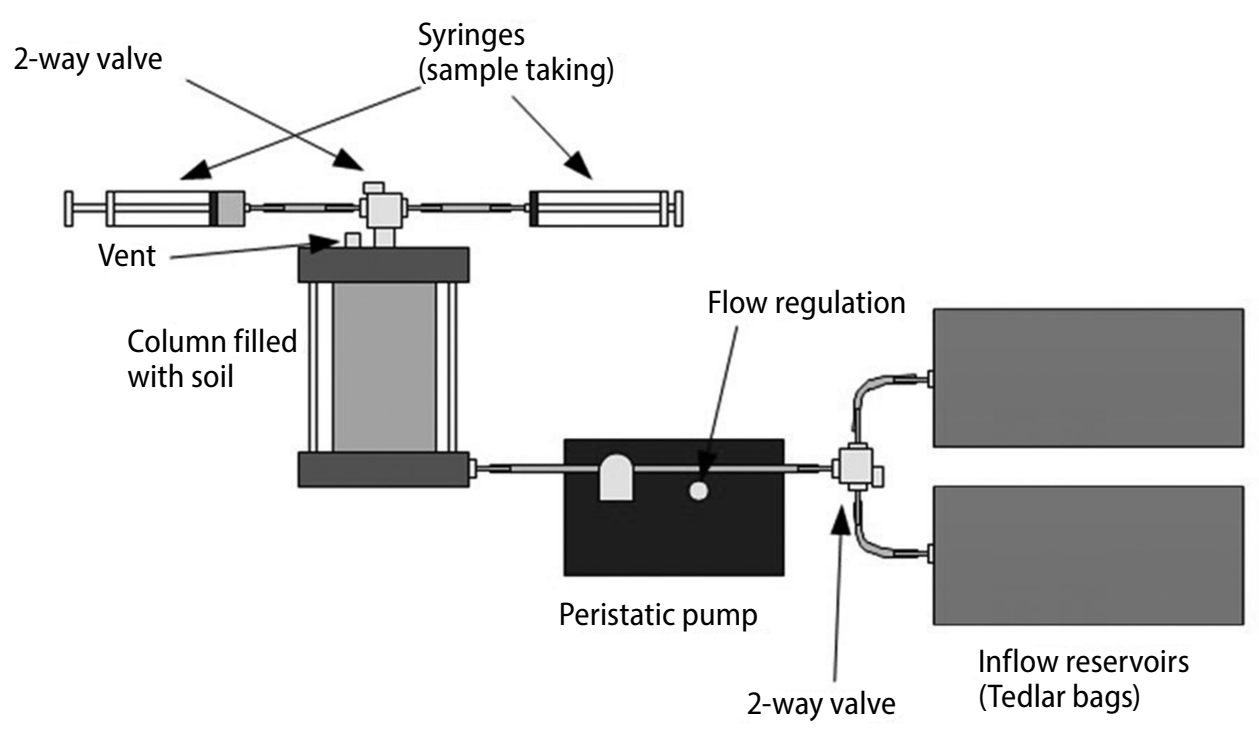

Fig. 1. The set-up for column experiments 


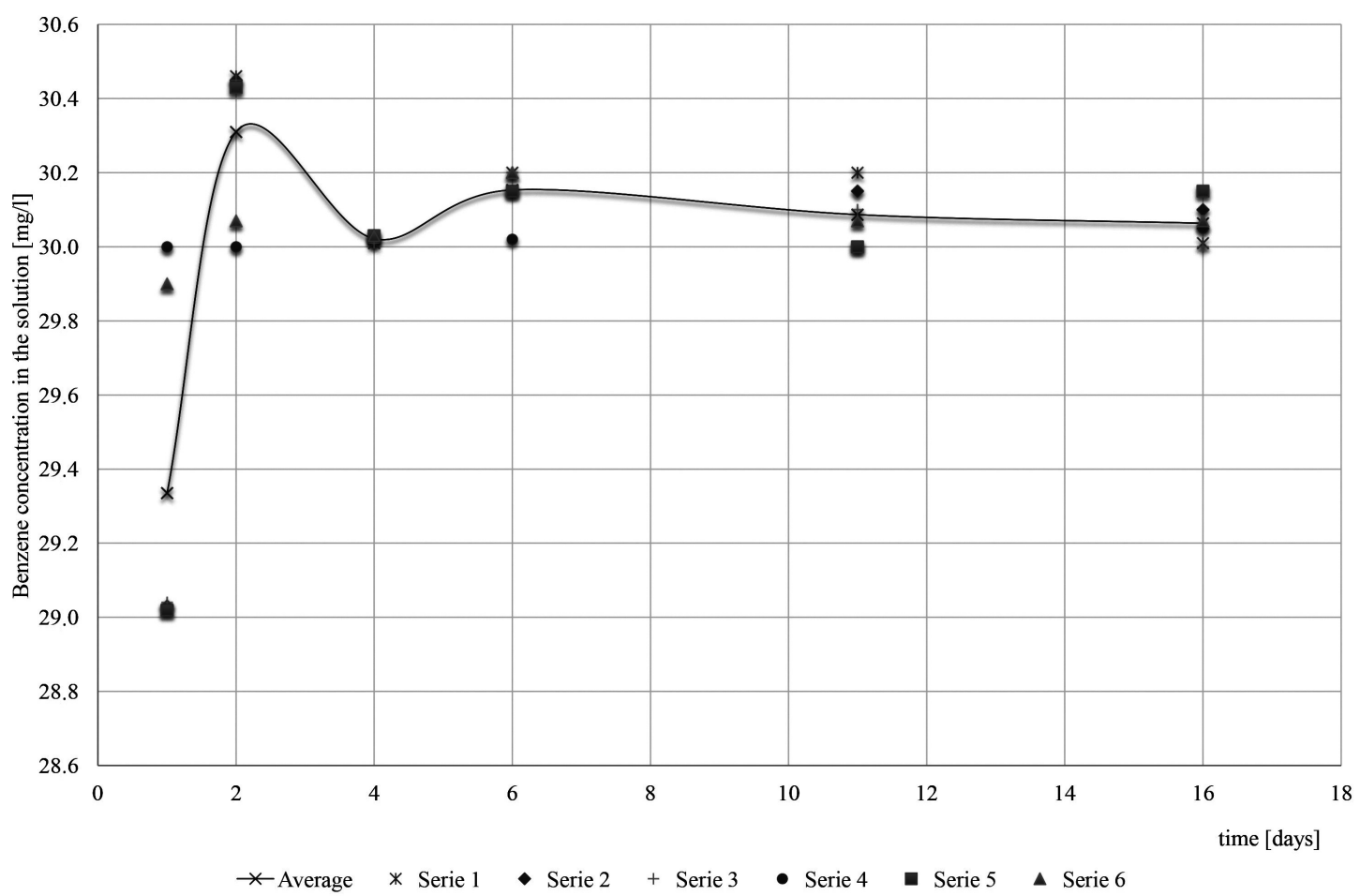

Fig. 2. Concentrations of benzene in the solution as a function of time

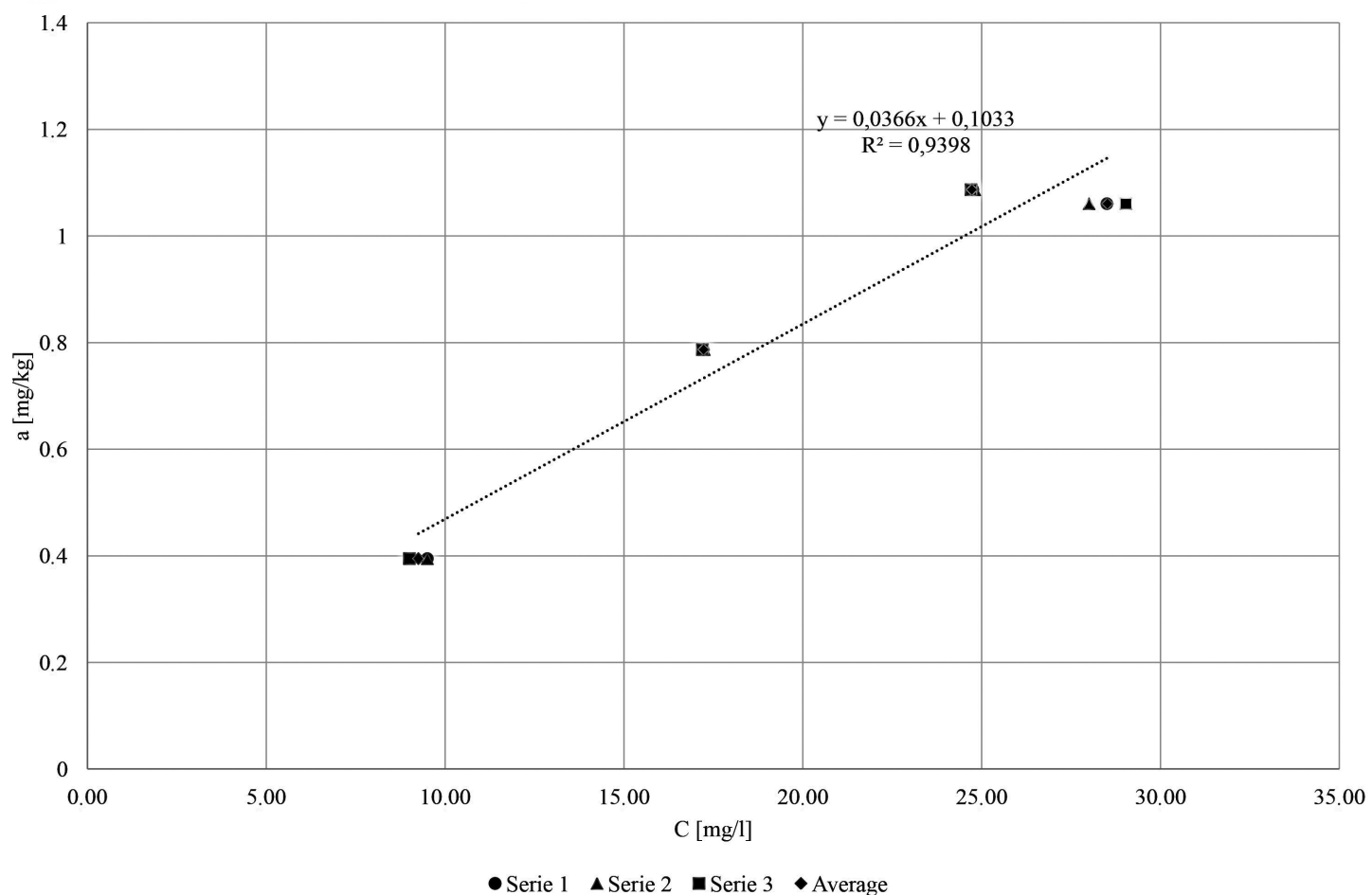

Fig. 3. The linear sorption isotherm derived from batch tests

The linear sorption isotherm (Fig. 3) was derived from batch tests results performed in three independent series. From the diverse sorption models tested the linear model was selected because of the sufficiently high correlation coefficient $\left(R^{2}=0.9398\right)$. The obtained values of $K_{d}$ varied from 
ca. 0.037 to $0.046 \mathrm{dm}^{3} / \mathrm{kg}$, with the average value of $0.042 \mathrm{dm}^{3} / \mathrm{kg}(\mathrm{std}=0.004(8.7 \%))$ (Tab. 3). The calculated mean retardation coefficient $R$ was of 1.21 .

Benzene and chloride concentrations in the solutions observed during the column experiment are summarized in Table 4 and presented graphically in Figure 4.
Figure 5 shows the average breakthrough curves (BFCs) of benzene and chloride ions obtained in the column tests. The average time of benzene migration $\left(t_{0}^{x}\right)$ and time related with the water flow velocity $\left(t_{0}\right)$ through the column with clays allowed to determine the retardation coefficient $R=2.0$ from equation (4).

Table 3

Partitioning and retardation coefficients derived from the batch sorption tests

\begin{tabular}{|c|c|c|c|c|c|}
\hline No. & $\begin{array}{c}\text { Initial benzene } \\
\text { concentration in solution } \\
{\left[\mathbf{m g} / \mathbf{d m}^{3}\right]}\end{array}$ & $\begin{array}{c}\text { Average benzene } \\
\text { concentration in solution } \\
\text { after sorption }\left[\mathbf{m g} / \mathbf{d m}^{3}\right]\end{array}$ & $\begin{array}{c}\boldsymbol{a} \\
{[\mathbf{m g} / \mathbf{k g}]}\end{array}$ & $\begin{array}{c}\boldsymbol{K}_{\boldsymbol{d}} \\
{\left[\mathbf{d m} \mathbf{m}^{3} / \mathbf{k g}\right]}\end{array}$ & $\begin{array}{c}\boldsymbol{R} \\
{[-]}\end{array}$ \\
\hline 1 & 30.53 & 28.5 & 1.061 & 0.037 \\
\hline 2 & 26.79 & 24.7 & 0.787 & 0.044 \\
\hline 3 & 18.72 & 17.2 & 0.395 & 0.043 \\
\hline 4
\end{tabular}

Explanations: a - sorption capacity, $K_{d}$ - partitioning coefficient, $R$ - retardation coefficient

Table 4

Results of the column experiment

\begin{tabular}{|c|c|c|c|c|c|c|}
\hline \multirow{2}{*}{$\begin{array}{l}\text { No. of } \\
\text { sample }\end{array}$} & \multirow{2}{*}{$\begin{array}{c}\text { Initial benzene } \\
\text { concentration in } \\
\text { solution } \\
{\left[\mathbf{m g} / \mathbf{d m}^{3}\right]}\end{array}$} & \multirow{2}{*}{$\begin{array}{c}\text { Average chloride } \\
\text { concentration } \\
\text { eluate } \\
{\left[\mathbf{m g} / \mathbf{d m}^{3}\right]}\end{array}$} & \multicolumn{3}{|c|}{$\begin{array}{c}\text { Benzene concentration } \\
\text { in solution after sorption } \\
{\left[\mathrm{mg} / \mathbf{d m}^{3}\right]}\end{array}$} & \multirow{2}{*}{$\begin{array}{l}\text { Time } \\
{[\mathrm{min} .}\end{array}$} \\
\hline & & & series 1 & series 2 & series 3 & \\
\hline 1 & \multirow{10}{*}{30.00} & 75.0 & 6.23 & 6.25 & 6.20 & 50 \\
\hline 2 & & 80.0 & 15.39 & 15.38 & 15.41 & 100 \\
\hline 3 & & 88.0 & 22.38 & 22.33 & 22.42 & 150 \\
\hline 4 & & 94.0 & 24.26 & 24.26 & 24.27 & 200 \\
\hline 5 & & 100.0 & 26.62 & 26.59 & 26.64 & 250 \\
\hline 6 & & 100.0 & 26.18 & 26.22 & 26.15 & 300 \\
\hline 7 & & 102.0 & 27.96 & 28.00 & 27.93 & 350 \\
\hline 8 & & 100.0 & 28.32 & 28.33 & 28.30 & 400 \\
\hline 9 & & 100.0 & 29.00 & 29.00 & 28.50 & 450 \\
\hline 10 & & 100.0 & 30.00 & 29.00 & 28.50 & 500 \\
\hline
\end{tabular}




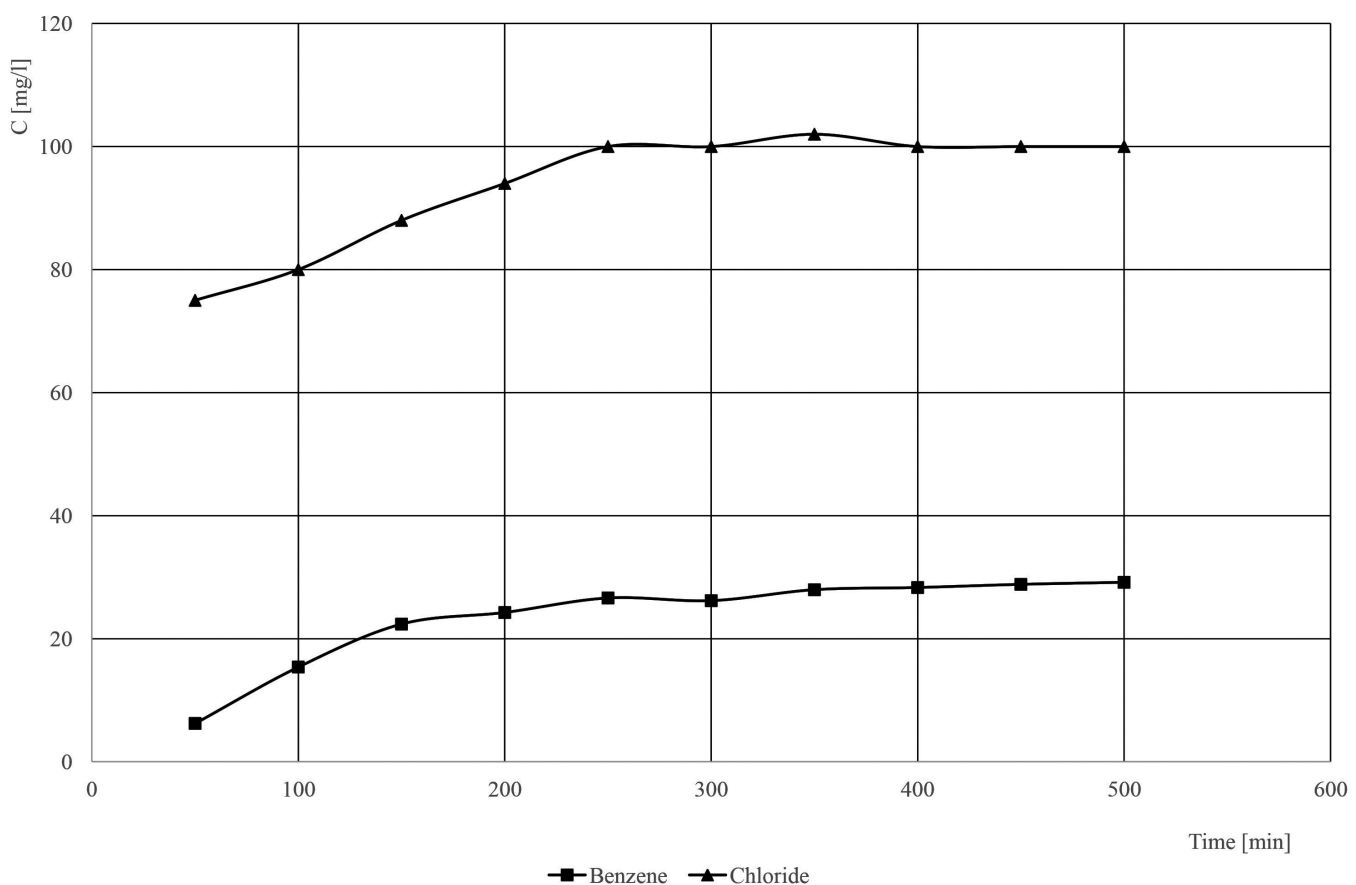

Fig. 4. The relationship between average values of benzene and chloride ions concentrations in the column eluate in time

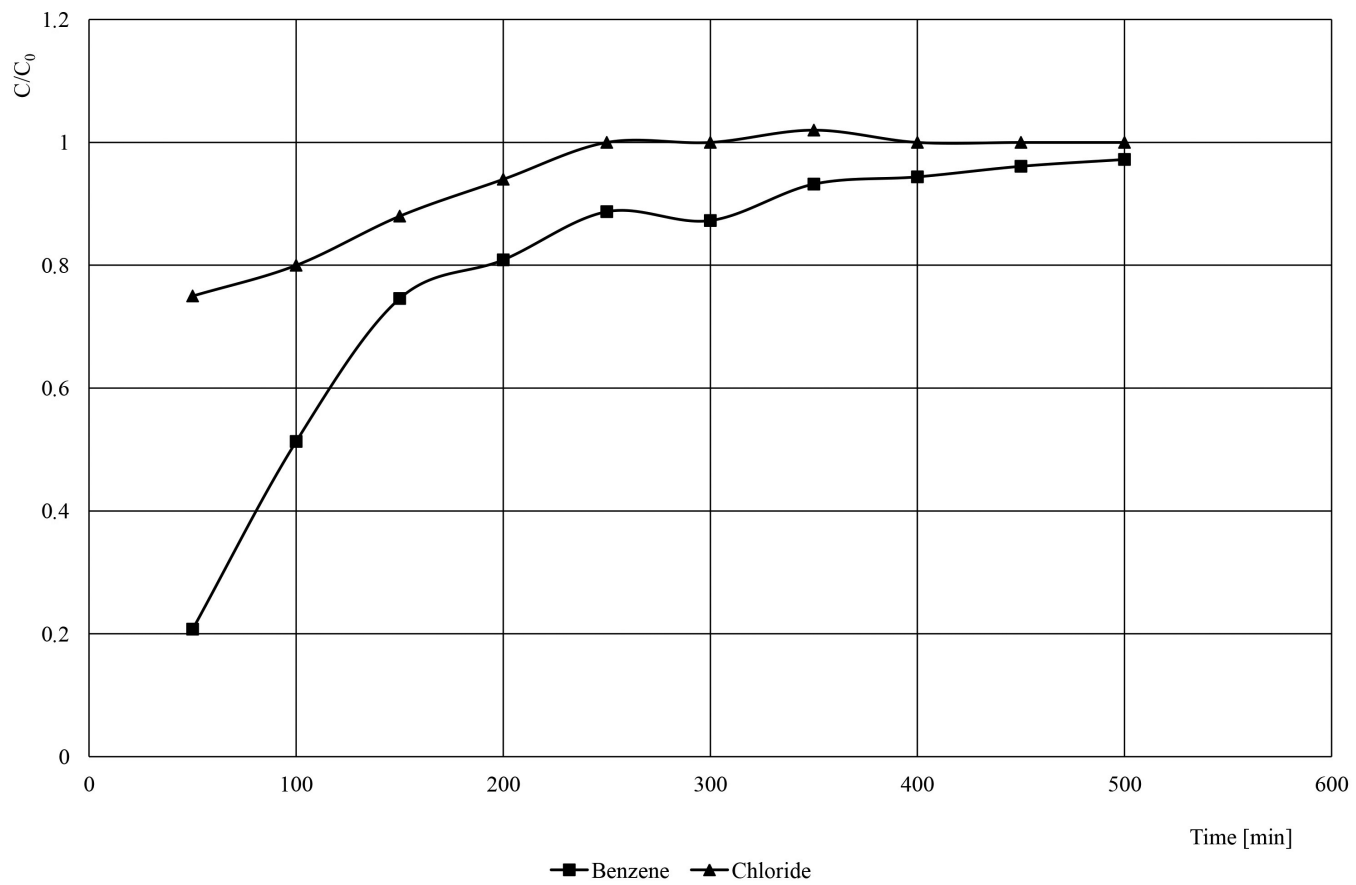

Fig. 5. The average breakthrough curves (BFCs) of benzene/chloride in the column test

\section{DISCUSSION}

The distribution constant $K_{d}$ is a measure of the distribution of the concentration of a substance between the solution and the soil under equilibrium conditions. The values of $K_{d}$ specify the distribution of contaminants in the environment components and can be derived from the sorption isotherms. In our study the linear sorption model was applied as it fitted well the experimental results 
(the correlation coefficient $R^{2}=0.9398$ ). A delay of benzene migration through the column with clays in comparison to the water flow velocity determined by the chloride ions used as a conservative tracer was due to its retardation caused by sorption on clays. For the tested clays benzene retardation coefficients calculated using two independent methods: the sorption isotherms and column test results were of 1.2 and 2.0, respectively. The obtained values are comparable and show small sorption according to the sorption intensity classes suggested by Osmęda-Ernst \& Witczak (1991) (Tab. 5). According to Calicki (2006) retardation coefficients for benzene in silty clays range from 0.8 to 2.4 and they tend to be higher for column experiments compared to the batch tests.

\section{Table 5}

Sorption intensity classes (Osmęda-Ernst \& Witczak 1991)

\begin{tabular}{|l|c|}
\hline Sorption intensity classes & Retardation coefficient $\boldsymbol{R}$ \\
\hline 1 - sorption doesn't occur & 1 \\
\hline 2 - small sorption & $1-2$ \\
\hline 3 - medium sorption & $2-10$ \\
\hline 4 - high sorption & $10-100$ \\
\hline 5 - very high sorption & $100-1000$ \\
\hline 6 - unlimited sorption & $>1000$ \\
\hline
\end{tabular}

The main problem when applying column experiments for low permeable materials is the flow control. The way of loading the column also needs a special attention because of possibility of prefferential water flow paths. The results obtained in this work need to be confirmed by further experiments with different conditions such as: water flow rate through the column and the mass of the column load.

\section{CONCLUSION}

The presented work focused on the sorption processes for determination of clay sorption properties for BTEX compounds. Clays as low permeable materials are ussually tested by batch experiments and applying the column setup requires some technical modifications. Although our column results were compatible with the batch tests and literature data, further studies in this field should cover different clay samples and experimental conditions to confirm the usefulness of dynamic tests for estimating sorption and other migration parameters of benzene (BTEX) in clay materials. Additionally, it is necessary to consider the mineral composition of investigated clays and different sorption models as it is important for the full explanation of sorption mechanisms.

Authors are grateful to the Reviewers for valuable advices and opinions.

\section{REFERENCES}

Ayala J., Vega J.L., Alvarez R. \& Loredo J., 2008. Retention of heavy metal ions in bentonites from Grau Region (North Peru). Environmental Geology, 53, 1323-1330.

Bolt A. \& Dobkowska M., 2000. Charakterystyka procesów naturalnej degradacji zanieczyszczeń BTEX w środowisku gruntowym. Jubileuszowa Sesja Naukowa „Geotechnika w budownictwie i inżynierii środowiska", Gdańsk.

Breus I. \& Mishchenko P., 2006. Sorption of volatile organic contaminants by soils (a review). Eurasian Soil Science, $39,12,1271-1283$.

Calicki P., 2006. Analiza porównawcza migracji produktów ropopochodnych $w$ różnych warunkach geologicznych $i$ hydrogeologicznych na przykładach skażeń gruntów $i$ wód podziemnych $w$ rejonach Białogonu, Skarżyńsko-Kamiennej, Tomaszowa Mazowieckiego, Słostowic oraz Retek. AGH, Kraków [PhD thesis, not published].

Delle Site A., 2001. Factors affecting sorption of organic compounds in natural sorbent/water systems and sorption coefficients for selected pollutants. A review. Journal of Physical and Chemical Reference Data, 30, 1, 187-439.

Greg S.J. \& Sing K.S.W., 1982. Adsorption, Surface area and porosity. Academic Press, New York.

Izdebska-Mucha D., 2005. Wpływ zanieczyszczeń ropopochodnych na wybrane geologiczno-inżynierskie właściwości gruntów spoistych. Przegląd Geologiczny, 53, 9, 766-769.

Izdebska-Mucha D., 2008. Pore space studies on Wartanian glacial till (Central Poland) polluted with petrol and diesel oil, based on mercury porosimetry. Geological Quarterly, 52, 2, 183-190.

Jeong J. \& Charbeneau R.J., 2014. An analytical model for predicting LNAPL distribution and recovery from multi-layered soils. Journal of Contaminant Hydrology, 156, 52-61.

Kubilay S., Gurkan R., Savran A. \& Sahan T., 2007. Removal of $\mathrm{Cu}(\mathrm{II}), \mathrm{Zn}(\mathrm{II})$ and $\mathrm{Co}(\mathrm{II})$ ions from aqueous solutions by adsorption onto natural bentonite. Adsorption, 13, $41-51$.

Macioszczyk A. \& Dobrzyński D., 2007. Hydrogeochemia strefy aktywnej wymiany wód podziemnych. Wydawnictwo Naukowe PWN, Warszawa. 
Malina G., 2011. Likwidacja zagrożenia środowiska gruntowo-wodnego na terenach zanieczyszczonych [wyd. 2 rozszerzone i zaktualizowane]. Polskie Zrzeszenie Inżynierów i Techników Sanitarnych. Oddział Wielkopolski, Poznań.

Małecki J.J. (red.), 2006. Wyznaczanie parametrów migracji zanieczyszczeń w ośrodku porowatym dla potrzeb badań hydrogeologicznych i ochrony środowiska. Poradnik metodyczny. Uniwersytet Warszawski, Wydział Geologii, Warszawa.

Marciniak M., Małoszewski P. \& Okońska M., 2006.Wpływ efektu skali eksperymentu kolumnowego na identyfikację parametrów migracji znaczników metodą rozwiązań analitycznych i modelowania numerycznego. Geologos, $10,167-187$.

Minnich M., 1993. Behavior and determination of volatile organic compounds in soil: a literature review. US Environmental Protection Agency Issue, EPA 600/R-93/140, Las Vegas.
Osmęda-Ernst E. \& Witczak S., 1991. Parametry migracji wybranych zanieczyszczeń $\mathrm{w}$ wodach podziemnych. [in:] Ochrona wód podziemnych w Polsce. Stan i kierunki badań, Publikacje CPBP 04.10., 56, Wyd. SGGW-AR, Warszawa, 201-215.

Pinedo J., Ibanez R., Lijzen J.P.A. \& Irabien A., 2013. Assessment of soil pollution based on total petroleum hydrocarbons and individual oil substances. Journal of Environmental Management, 130, 72-79.

Qu F., Zhu L. \& Yang K., 2009. Adsorption behaviors of volatile organic compounds (VOCs) on porous clay heterostructures (PCH). Journal of Hazardous Materials, 170, 7-12.

Rembeza L., 1998. Przeplywy wody i zanieczyszczeń w gruncie. Analityczne metody rozwiązań. Wydawnictwo AR, Poznań.

Witczak S. \& Adamczyk A., 1995. Katalog wybranych fizycznych i chemicznych wskaźników zanieczyszczeń wód podziemnych i metod ich oznaczania. T. 2. Biblioteka Monitoringu Środowiska, Oikos, Warszawa. 